\title{
A Visualization and Representation of the Culture in Yawan, Papua New Guinea: Drawings in the Context of a Visual Anthropology
}

\author{
Martin Soukup \\ The Department of Cultural Studies (Culturology), Faculty of Arts, Charles University in Prague, Celetná 20, 11000 Prague 1 \\ Received 10 September 2011; accepted 26 October 2011

\section{VIZUALIZACE A REPREZENTACE KULTURY V YAWANU, PAPUA-NOVÁ GUINEA: KRESBY V KONTEXTU VIZUÁLNÍ ANTROPOLOGIE}

\begin{abstract}
ABSTRAKT Předmětem studie je analýza obrazového materiálu, který autor získal při výzkumném pobytu ve vesnici Yawan, provincie Morobe, Papua-Nová Guinea. Autory analyzovaných obrázků jsou žáci základní školy ve vesnici Yawan. Jednotícím motivem všech získaných obrázků je kultura, kterou měli žáci na svých obrázcích ztvárnit. Na obrázcích autoři zachytili bez výjimky kulturní prvky tradiční kultury. Autor dává obrázky do souvislosti s povědomím tvůrců o rozdílech mezi tradiční a současnou kulturou a výchovou těchto žáků k péči o kulturní tradice. Autor následně dal výsledky analýzy do souvislosti s hloubkovými rozhovory, jež vedl s několika původními obyvateli Papuy na téma koncepce kultury a kulturních změn v této zemi.
\end{abstract}

KLÍČOVÁ SLOVA vizualizace kultury; kultura; Papua-Nová Guinea

\begin{abstract}
The aim of this study is to analyze visual materials gathered during my research time in the village of Yawan in the province of Morobe, Papua New Guinea. Analyzed pictures were drawn by local elementary school children. The uniting theme of all pictures is a culture as a subject the Yawan pupils were asked to depict. Without exception, their pictures depict the cultural aspects of their traditional culture. Author finds a connection between an inherent knowledge and distinction between modern and traditional culture and their education that nurtures the awareness of their cultural traditions. The author also conducted many in-depth interviews with the native inhabitants of Papua on the subject of cultural concepts and cultural changes in their country and links them with his findings of the picture analysis.
\end{abstract}

KEY WORDS Visualization of Culture; Culture; Papua New Guinea

\section{INTRODUCTION}

The old anthropological joke says that a typical Papuan family includes mother, children and father-anthropologist. The anthropology and anthropologists are very popular in Melanesia. We should not be surprised because Europeans have been researching local communities in Melanesia since the seventies of the $19^{\text {th }}$ century (Soukup 2010). During my stay in Papua New Guinea I faced the popularity of anthropology myself in 2009. After the landing in Yawan village I did not need to explain who I am and why I have come to them. The teach- ers of local elementary school asked me, if I can give a lecture to their students. The demand topic was evident: What is anthropology, what culture is and why they have to protect their vernacular (or tok ples in Pidgin English). They really used the word anthropology and culture. From the anthropological point of view this circumstances were paradoxical and bizarre. Anthropologists and natives switched their roles, the natives transformed anthropologist into the object of inquiry. Moreover they used the concept of culture as their gnoseological tool. This is the opposite experience then a British social anthropologist Nigel Barley (born 1947) gained among Dowayo 


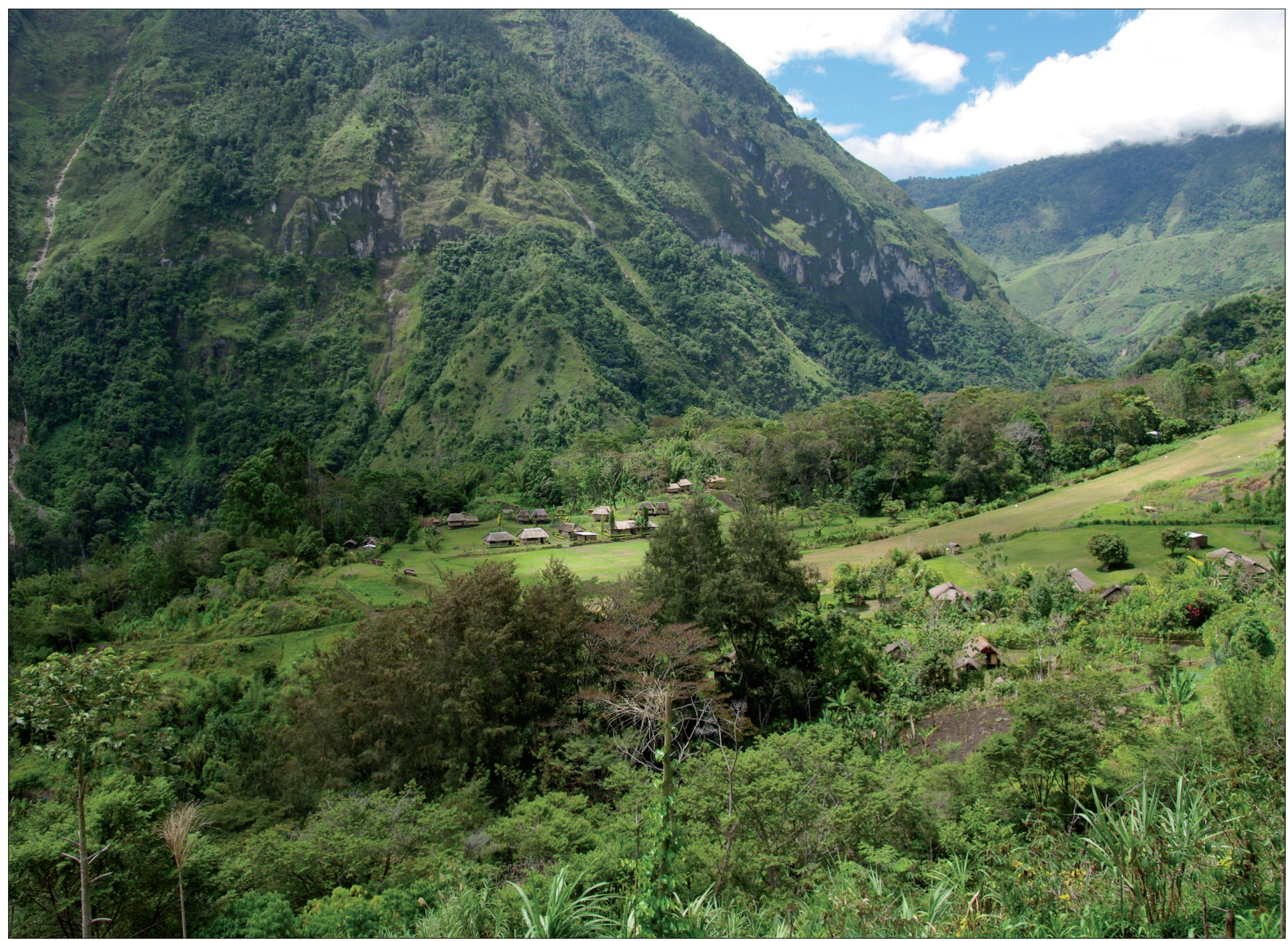

Fig. 1. Yawan village. Author: Martin Soukup.

in Cameroon during his field work. He had to face bizarre and funny difficulties conducting field work and applying standard anthropological research tools (Barley 1983). Compared to him and Dowayo few Yawan villagers were familiar with anthropology and what anthropologists do.

Melanesia (or „black islands") includes a group of islands and archipelagoes in Pacific. It is the part of Oceania, which except Melanesia covers also Micronesia and Polynesia. This area takes in for example New Guinea, New Caledonia, Admiralty Islands, New Ireland, Loyalty Islands, Bismarck Archipelago, Santa Cruz, New Hebrides and Fiji. Anthropologists consider Melanesia as a relatively homogenous cultural area. On the other hand, many anthropologists criticize this point of view. They argue that a fabulous cultural diversity of Melanesia makes it inconceivable to understand this area as a unified cultural area (Carrier 1992). Despite this variability one can identify a few common cultural denominators across the Melanesia. I should highlight the sociopolitical exchange, the big-manship, pigs herding as symbol of luxury, cargo cults and many others. However one has to be careful when identifying the concept of Melanesia.

New Guinea is a extraordinary part of Melanesia. Politically it is divided between Indonesia and an independent state of
Papua-New Guinea. New Guinea is the world's second largest island; its an acreage is nearly eight hundred thousands kilometers sq. Human population colonized this land at least forty thousands years ago. It embodies a fabulous cultural and a linguistic diversity as well as biodiversity and was at the end of the world's map, where one had to type proverb "hic sunt leones". The areas of central highlands remained unknown till the thirties of the $20^{\text {th }}$ century. All these facts naturally led to the scientific interests in New Guinea. Since the end of the $19^{\text {th }}$ century New Guinea has been the object of anthropological research. Anthropologists during this very long period studied local cultures of New Guinea in all parts of the island. One of the outputs of this scientific effort is to import anthropological concept of culture among natives.

The Yawan area is situated in the Finnisterre Range of Morobe province (figure 1). This area is a rather remote part of Papua New Guinea. The Yawan area is located in YUS Conservation Area which was the very first protected area under the Conservation Areas Act from 1978 (Montgomery and Bishop 2006, West 2006). The conservation Area is bisected by the Yopno, Uruwa and Soma rivers. YUS Conservation area was open in April 2009. The Yawan area consists of six villages Yawan, Toweth, Kotet, Mitmit, Worin and Mup. Based on my 
subjective observation I would estimate there are around one thousand people in the Yawan region. Yawan is the name of one village in the Yawan area. Yawan communities are based on patrilinear clans and apply patrilocal rule of postmarital residence. Linguistically they are part of the Yau (Lewis 2009). People of different villages speak with dialects of one language which means they all understand each other. Regardless of small differences between artifacts, languages and ideas in each village of the Yawan area we still speak of one culture. The subsistence strategies are predominantly grounded in gardening supported by hunting and gathering. Yawan communities are increasingly influenced by western civilization. A few major changes are: (1) concerning established YUS Conservation Area the communities abandoned the hunting of some species of animals. (2) Ideational system is under long-term impression of missionary activities in this area. (3) The necessity of communication with the outside world strengthens the importance of Pidgin English as the main communication tool inside and outside Yawan communities.

\section{VISUALIZATION OF CULTURE IN THE FINISTERE RANGE OF NEW GUINEA}

The research of local cultures of Papua New Guinea via drawings is not an unique one, but is rare. One of the first examples of drawings made by Melanesian natives were gained by participants of a famous expedition to the Torres Strait in 1898 led by British naturalist and self-made anthropologist Alfred Cort Haddon (1855-1940). He published some of the drawings in the first volume of Reports of the Cambridge Anthropological Expedition to Torres Straits (192-1935). In this work we can study the figuration of the mythical being Terer and Aukem, which the dwelers of Mer island made (figure 2) (Haddon, 1935: 118). Only a few recent anthropological works are focused on visualization via drawings made by the inhabitants of Papua New Guinea. Margaret Martlew and Kevin Connolly (1996) were concerned with the human figures drawn by children from New Guinea Highlands. This type of research is unique. In other words, it is possible to conclude that a study of culture via visualization is a very underestimated part of our field. In doing this type of research, an anthropologist can use various methods and analytical tools of visual anthropology, cultural psychology as well as of an art therapy.

Generally, it is possible to conclude that this type of a study is a part of a visual anthropology as a subdiscipline of the cultural anthropology. Unfortunately, representatives of visual anthropology tend to see their field as a study of a culture through the lens of a camera (Grimshaw 2001). I find this conception rather reductive. The groundwork for a visual anthropology was built by travelers, missionaries, civil servants and painters. They wanted to mediate "a picture of others" by means of an art. In this context we can designate as extraordinary the woodcut shown in the work of travelers Hans Staden (15251597) and Jean de Léry (1534-1613), aquarelles of natives of Florida made by John White (1540-1593), oil paintings by

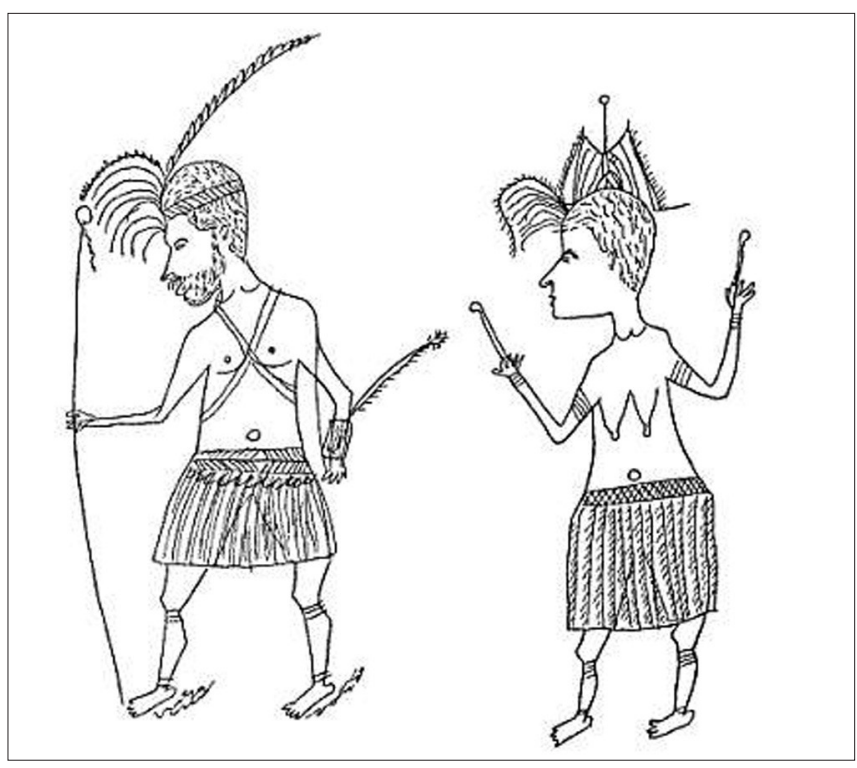

Fig. 2. Terer and Aukem, Mer Island.

Albert Eckhout (?1610-1665), paints of Iroquois drawn by John Verelst (?1648-1734), or lithographies of Aborigines made by Charles Alexandre Lesueur (1778-1846). Unfortunately, current visual anthropology is predominantly framed as the study of the culture via lens (Soukup 2011). Despite the postmodern discourse, whose proponents deconstructed anthropology and what anthropologists do, the anthropology is still understood as a science. It means emphasis on the accuracy and the objectivity. Unlike the drawings, the camera lens offers a basis for objectivity. Maybe that is why the above mentioned artists belong to the forgotten roots of a visual anthropology. Disregarding visual means is not objective an sich. If it was, then Flaherty's protagonist of Nanook of the North would not catch a cold; his would-be ethno-reality-movie is not rare. For instance I can recall an ethnographic fimaker such as John Marshall or Jean Rouch (Weinberger 2011). Apart from these issues I am convinced that a visual approach to culture allows us to use a wide spectrum means and one of them is drawings made by natives.

The use of anthropological categories by Yawan villagers interested me in so far that I acceded to the demand; I hade gave the lecture on anthropology, culture and vernacular. After this business auditorium I asked pupils of the elementary school to make drawings on the theme of culture. Simultaneously I asked them to draw a map of their village; i.e. I gathered mental maps (Bláha - Soukup - Balcerová, 2011). From the students of the Yawan elementary school I gathered thirty five drawings of culture. Their authors used pencils, crayons and markers. The painters dwell in all above mentioned villages. There is just one exception; one pupil came to Yawan from the Teptep village. He moved from Teptep together with the teacher who was appointed to the Yawan. The age composition is as follows: the sample consists pupils fromthe age of nine to twenty five. The sample includes just one painter at the age of twenty five and one of twenty four. The age average 
is seventeen. The broad age composition is due to opening of Yawan elementary school until quite recently (2004). All acquired drawings display traditional Papuan culture (see table 1). The two most frequent topics are kundu drum and tapa cloth respectively. Both of them are pictured ten times. Authors often choose human figure as a topic of their drawings; in sum five times. The pupils rarely drawn a necklace, a stone axe or a clay pot. They uniquely shaped a head dress, a string bag (bilum) and a local architecture.

\begin{tabular}{|c|c|c|}
\hline Theme & Frequency & male / female \\
\hline Kundu drum & 10 & $6 / 4$ \\
\hline Tapa cloth & 10 & $5 / 5$ \\
\hline Human figure & 5 & $3 / 2$ \\
\hline Clay pot & 3 & $1 / 2$ \\
\hline Necklace & 2 & $2 / 0$ \\
\hline Stone axe & 2 & $2 / 0$ \\
\hline Headdress & 1 & $1 / 0$ \\
\hline House & 1 & $1 / 0$ \\
\hline Net bag (bilum) & 1 & $0 / 1$ \\
\hline
\end{tabular}

Tab. 1. Frequency of the themes in the drawings.

The most significant motif of the Yawan pupils' drawing was tapa cloth, which is diffused across Oceania. Tapa is made by felting phloem. The tapa is most widespread in Polynesia; for exemple in Samoa and Tonga. The People of Melanesia made tapa also as for example in Fiji (Welsch 1998) and Papua-New Guinea, of course (f. e. Bodrogi 1961). In the Yawan area is tapa traditional part of the dressing. The tapa is in vernacular called tik. The tapa was variously colored and designed (design is called orip). My informants told me that there are not prescribed patterns. It depends just on the imagination and creativity of an owner or maker, which design is shaped on the tapa. But designs are records of natural and spiritual phenomenons. Highly abstracted visions are given by spirits (Wegmann 1990). The most frequent colors of the style are black and red. These ones are widely used colors in New Guinea; black and red are also state colors. These colors the pupils often used to design their drawings (figure 3).

The second most frequent theme of the gathered drawings is $k u n d u$ drum. The fabrication and using of the drums is widespread throughout Papua New Guinea. There has been inexhaustible plurality of its shape and decoration. This type of artifact is made of trunk; typically, the wood of Cordia subcordata (Bodrogi 1961) is used. Drum is approximately one meter long and is coverd with reptile skin. The player tunes the drum by a resin and the heat of a fire. Performer plays the drum with fingers of one hand; the second hand holds the instrument. The menn play the drum during feasts called in Pidgin English singsing. These celebrations take place on various type of occasions as for example childbirth, initiation marriage, and funeral and so on. Singsings and their specific features and progressions in different localities create a basis for communal as well

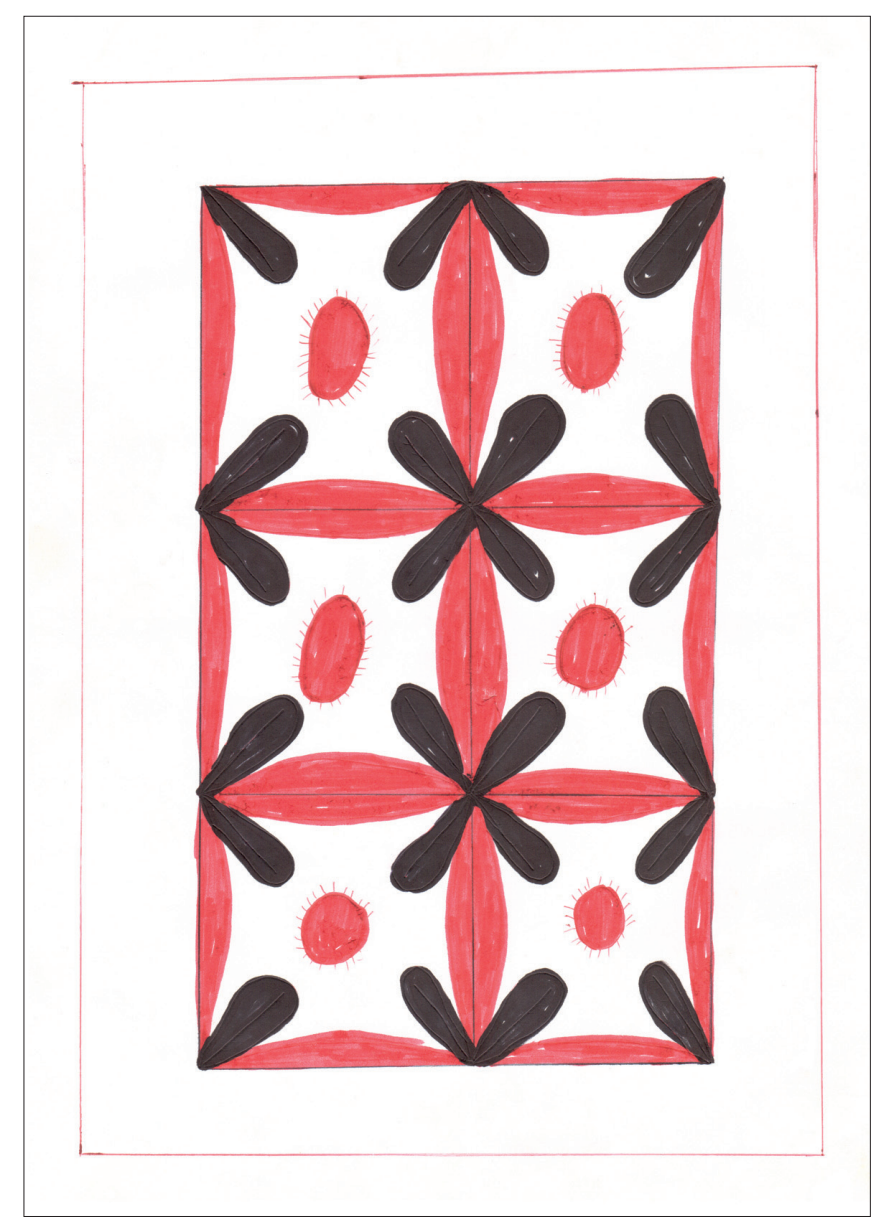

Fig. 3. Tapa cloth, red and black colors.

as an individual identity. May be that is why is kundu drum frequently shaped on the pupils' visualization of culture. Authors of some drawings combined motif of kundu drum with others cultural elements as for example necklace of board's tusks or bow and arrows (figure 4).

The third most frequent motif of the drawings was the human figure. In sum, the pupils drawn five times the human figure. On the basis of decorations of the figures it is possible to assume that these ones are men without an exception. It's compatible with the typical dominance of men in Melanesian societies. Two of five drawings contain certain context of the depicted person. On one occasion author located figure in the landscape (figure 5). In the second case there is a person anchored in the insignificant space; so to speak, this figure stands with feet solidly on the ground. Common denominators of the human figure drawings are decorations and artifacts for the singsing. Man hold kundu drums, wear headdress and board's tusks or shell necklace, and is equipped with bow and arrows. Some gained visualizations of culture contain pretty complicated combination of symbols and typical cultural elements of Papua. For example seventeen young girl choose as theme kundu drums, which is carried by bird. It is just possible to guess, if the portrayed bird is bird-of-paradise, which is state symbol of Papua New Guinea. This motif was use by the girls 


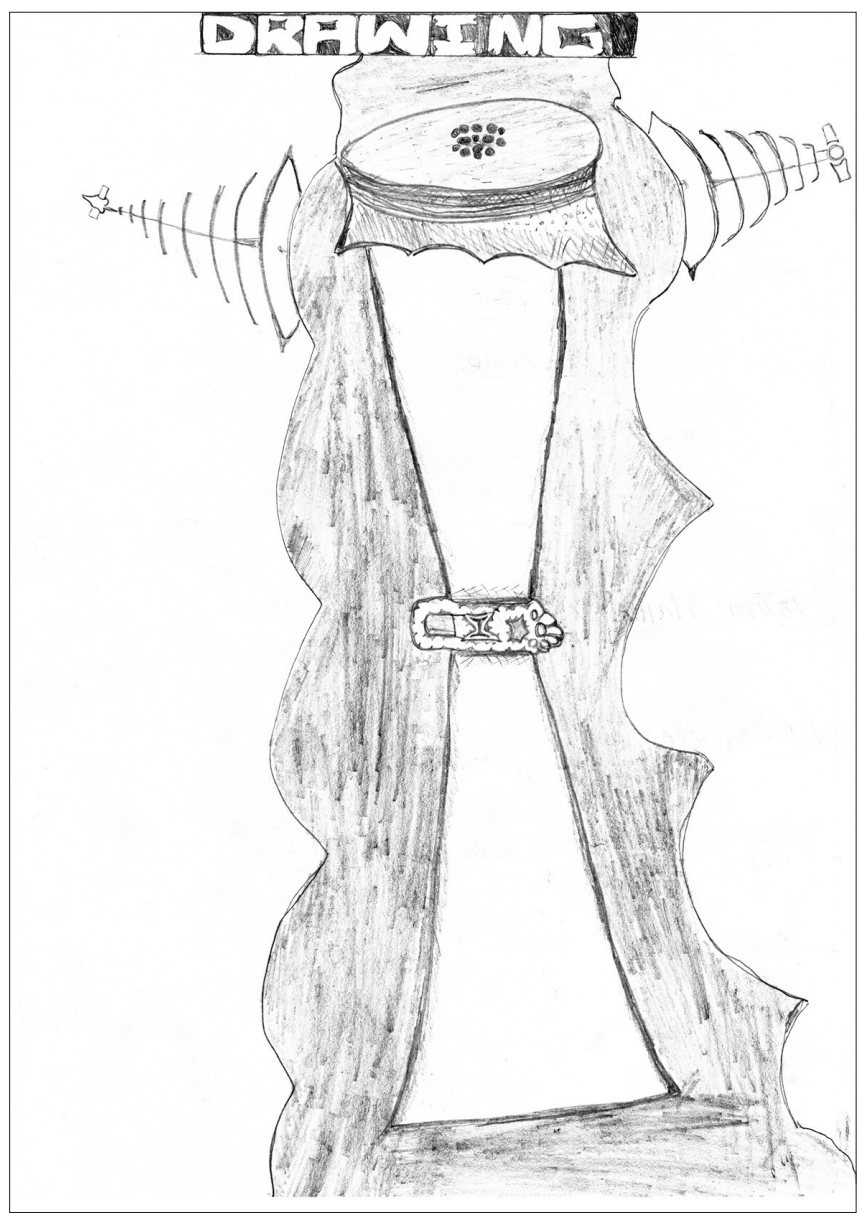

Fig. 4. Kundu drum.

as a decoration for the tapa cloth. Interesting is that the pivot theme author repeats on the border of drawings as a bordure. Some of the bordures are manufactured in details; others just as sketches (figure 6).

As an example of a rarely displayed theme I choose a stone axe, which is on the two of gathered artwork (figure 7). The stone axe is a very traditional type of artifact in Papua New Guinea. Human populations have used stone axe for thousands years. On the Huon peninsula archaeologists revealed very old evidence of human settlements. They discovered plenty of blades of stone axe during their field-work. The trasological analysis implies that people applied these artifacts people at the hardwork. The dating of this archeological remains revealed that human populations inhabited New Guinea at least forty years ago (Groube 1986). The Stone axe was not only universal tool (garden clearing or fence and house building), because many communities used them as valuables in the socio-political exchange. Tsembaga Maring (Simbai Valley) participated in exchange with communities in Jimi Valley. These groups traded manufactured salt for stone axes (Rappaport 1984). Besides this "economic" activity people of Highlands used to pay with the stone axes for brides (Brown 1979). In this context it is possible to interpret the above disscused types of artifacts as objects with the ascribed cultural meanings. A kundu drum, tapa

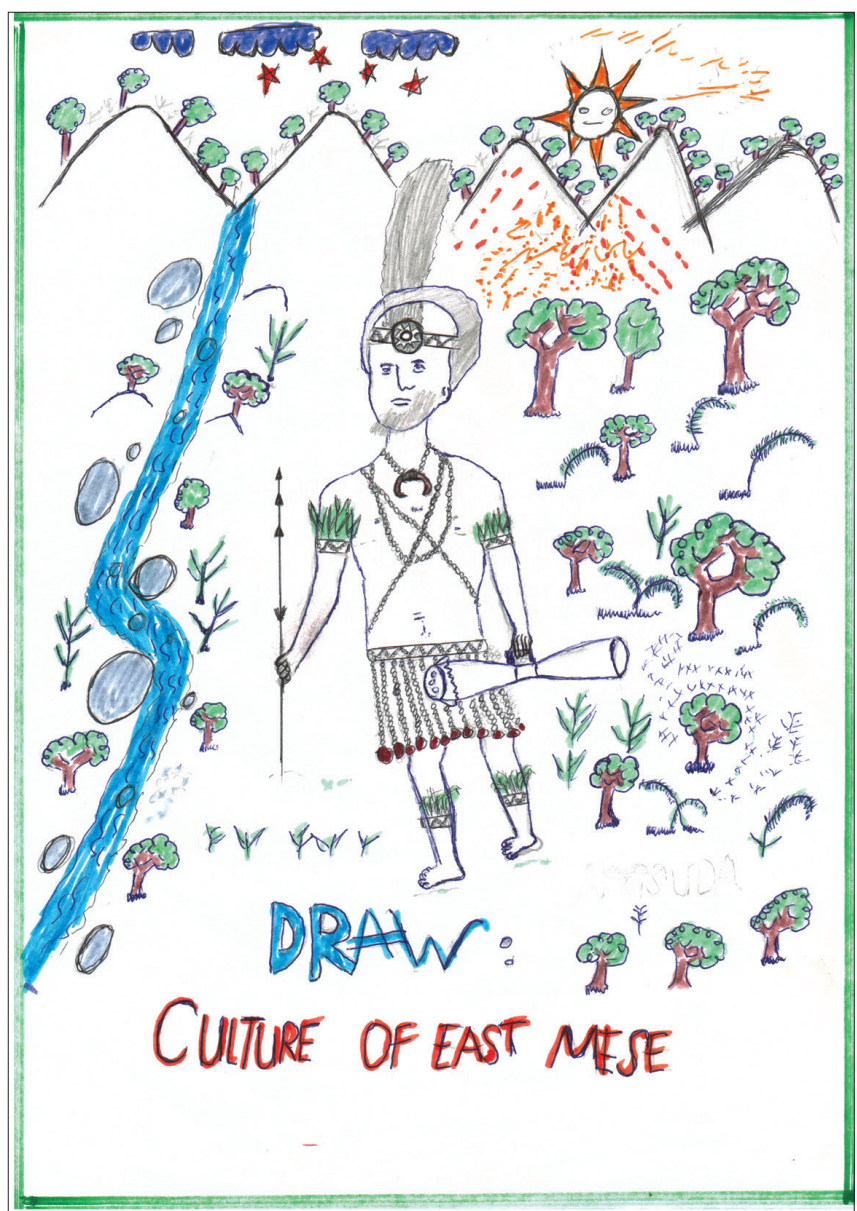

Fig. 5. Human figure.

cloth, or a stone axe are not just artifacts but they carry cultural meanings; moreover they are the key for Papuan culture. I think of the human ability to ascribe meaning to objects and phenomenons as a faculty distinguishing humans from others species (Soukup 2009).

The fact that authors pointed out elements of traditional cultures can be possibly interpreted as expression of awareness of differences between traditional and current local culture. Here is question how the pupils acquired this clear mental distinction. May be the teachers of local school taught them this issue. The teachers demand from the students to come to the school dressed in traditional clothes a once in week. Topic of the day is then local culture and vernacular. Students have to present their dress and explain purposes and meanings of the details of cloth. This systematic pedagogical approach the teachers care for cultivation of cultural identity and preservation of local culture. The gained drawings show evidences of a success. No drawing contains cultural elements essentially linked to the Euro-American cultural area, though the Yawan people face this objects and ideas of Euro-American origin on daily basis. This interpretation is supported by the fact that no drawing contains Christian symbols, despite the fact that Yawan people are Christians for at least sixty years. For a long period of time the Lutherans and the Adventists have operated in the Yawan 


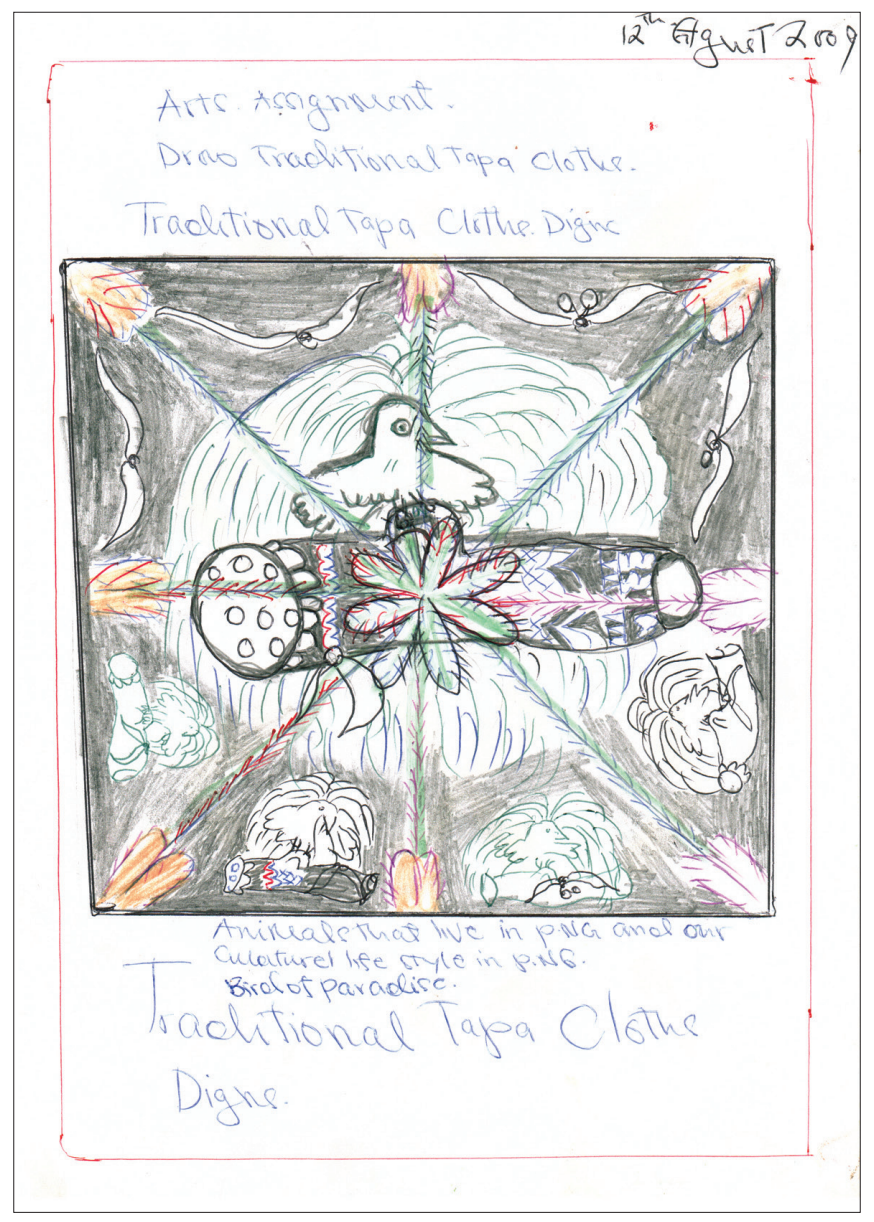

Fig. 6. Tapa cloth with bordure.

area. There is a church in the Kotet village, in which services take place. Moreover in the time of my stay there were questions of beliefs theme of the days. The natives recalled that in the Yawan area Lutherans and Adventists have been in a conflict for more than forty years. The ethnohistory of the missionization described by natives is different from the account given by Urs Wegmann (1990). The Lutheran mission came into Yawan area in 1945 and missionaries established a Lutheran missionary station and actively operated there for almost six years. After a violent conflict between the missionaries and the natives, the missionaries left in 1951. In 1964 Adventist missionaries arrived and took over in the area. As many people converted to Adventism the conflicts have arisen. Lutheran missionaries returned in 1971 and reclaimed Yawan area. Subsequent clashes between churches had a disturbing impact on Yawan communities. The Lutheran mission left Yawan area again in 1979. In the following years the Lutherans in Yawan area lived without any church support (services, baptism etc.). Finally in 2009 representatives of the Lutheran church returned and tried to re-establish an active Lutheran church in Yawan communities. This effort for a reconciliation took place in the period of my study of Yawan culture. I witnessed three day feast of an appeasement (figure 8). Surprisingly the pupils did not use Christian symbols in the drawings. The Christian object appeared

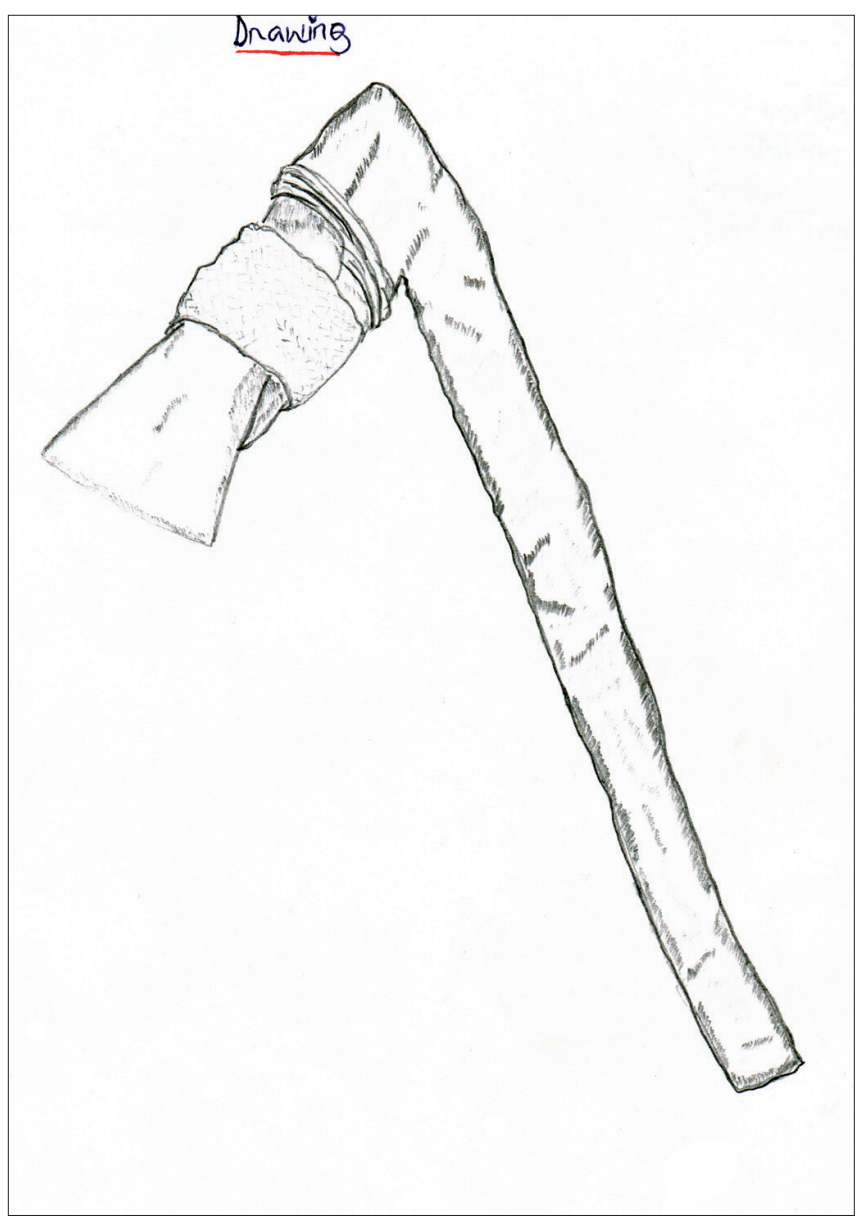

Fig. 7. Stone axe.

only once in gathered mental maps, which relate to the culture drawings only loosely (Bláha, Soukup, Balcerová, 2011). All gathered visual data therefore support idea that Yawan people both very well know what culture is and understand differences between traditions and current culture.

\section{CONCEPT OF CULTURE IN THE NATIVE'S POINT OF VIEW}

I am not the first who experienced the natives of Papua New Guinea using anthropological terminology. Considering that the vocabulary of Melanesian Pidgin English (tok pisin) includes the word kalsa in the meaning of culture. It is not unique that an anthropologist cooperates with members of a community who understand what culture is; i.e. culture as shared phenomenon, a basis for individual identity. Frederick Errington a Deborah Gewertz described their experiences acquired in Papua New Guinea. They concluded that "...virtually every one was self-consciousness about ,culture... Culture was understood by Chambri of the East Sepik Province as a priori, ontological, and collective - as the ultimate and enduring basis of local value and power" (Errington \& Gewertz 1996: 114). From time to time anthropologists meet the 


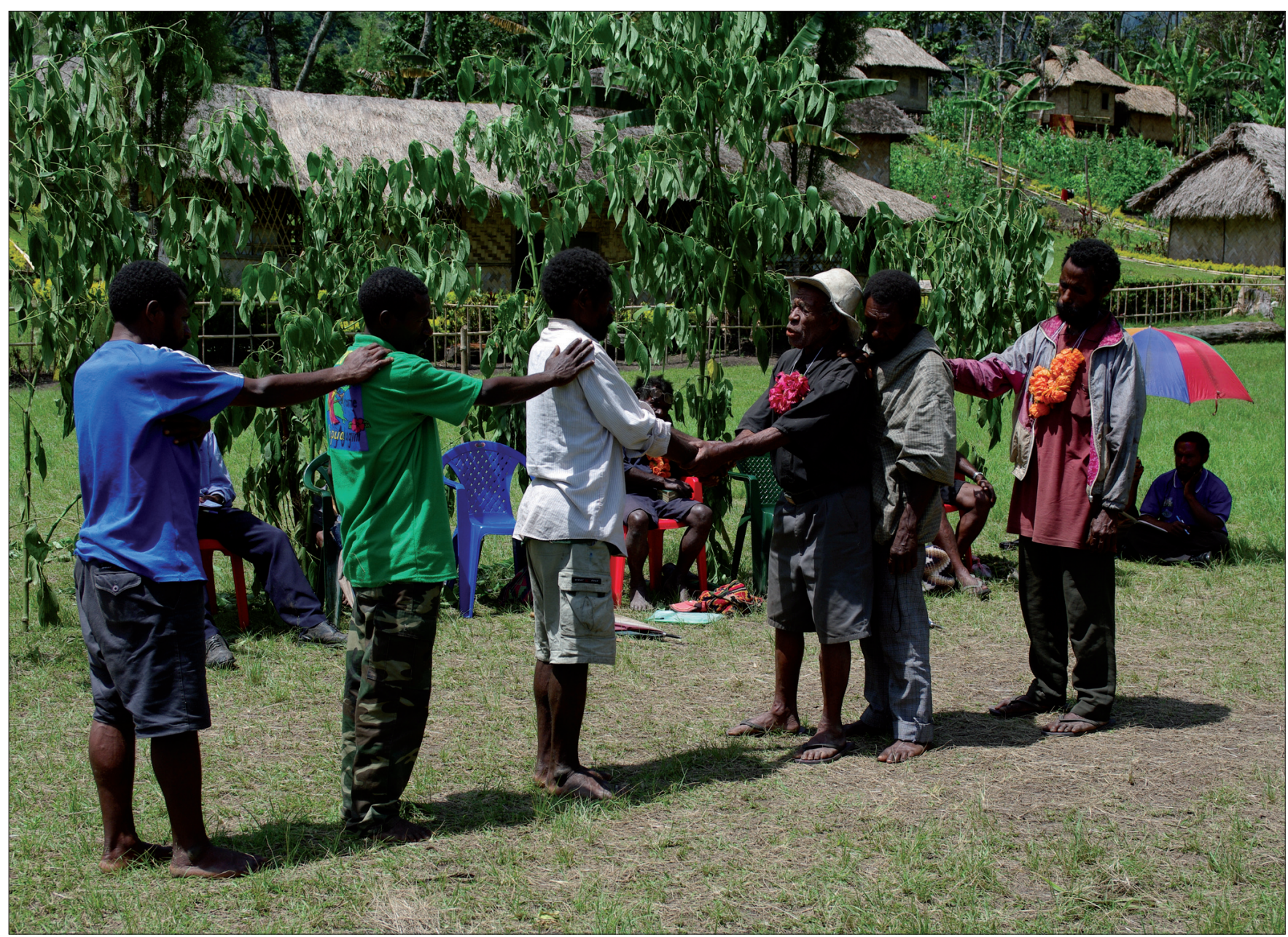

Fig. 8. Celebration of the reconciliation. Author: Martin Soukup.

people familiar with anthropology during their field-work; or even graduated in anthropology. This is experience above mentioned Bailey. One of his Indonesian informants showed him his master thesis in anthropology (Barley 1988: 85).

The question of understanding culture by natives of Papua New Guinea had interested me in so far that I have decided to conduct a short survey concerning concept of culture from the Papuan perspective. After my arrival from Yawan to Madang city I prepared forms for a semi-structured interview. I carried out a survey among the staff of one Papuan research institution. Its members originated in different provinces of Papua New Guinea. The structure of my sample was following: nine natives participated in the survey, eight men and one woman of the age of twenty three to thirty three. Four of them received B.A. in the natural science. Three of them were married, one of them had a child. From the methodological point of view I decided to use a semi-structured interview, which proceeded in English or Pidgin English. In the interviews I focused on the discussion of sociocultural changes and value attitudes. In other words, I aimed at culture concept and a evaluation of progressing sociocultural changes. This survey is not representative of course. But it illustrates Papuan notion of culture as well as attitudes of natives to the outer-word.

First of all I focused on the concept of culture. I asked the question: "If I say 'culture', what do you imagine". All respondents understood culture in the wide anthropological sense; i.e. they used word culture in a non-axiological sense (see table 2). So one respondent from Morobe Province said that culture is "way of everything we do, from farming to spells". Another one from Madang province defined culture as follow: "group of people, who are unique, they doing their life in their way, dressing or so". Respondent from Kainantu told me that "culture is a way of living that is influenced by parents and community around and by learning and observing. You learn and learned by. Way of doing things in community". It is possible to label all the gathered definitions as relevant from anthropological perspective. A few of them show high level of generalization and correspond with a recent anthropological theory of culture (definition \# 3, 4, 8). Moreover five of them imply differences between the past (traditional) way of life and the current state of culture influenced by Westerners (definition \# 2, 5, 6, 7). One respondent had awareness of cultural and linguistical diversity of Papua, when he said "Language (my tok ples), my singsing". 


\begin{tabular}{|c|c|c|c|c|c|}
\hline \multicolumn{6}{|r|}{ If I say 'culture', what you imagine? } \\
\hline & Age & $\operatorname{sex}$ & education & locality & Definition of culture \\
\hline 1 & 24 & M & BA & $\begin{array}{l}\text { Eastern } \\
\text { Highlands }\end{array}$ & $\begin{array}{l}\text { Culture is way of living that is influenced by parents and community around } \\
\text { and by learning and observing. You learn and learned by. Way of doing things } \\
\text { in community. }\end{array}$ \\
\hline 2 & 31 & M & BA & $\begin{array}{l}\text { East New } \\
\text { Britain }\end{array}$ & $\begin{array}{l}\text { Language (my tok ples), my singsing, traditional style of cooking, solving prob- } \\
\text { lems, building houses, gardening, traditional style of healing, way of thinking; } \\
\text { rituals, customs. Way of behaving. }\end{array}$ \\
\hline 3 & 27 & $\mathrm{~F}$ & BA & $\begin{array}{l}\text { West New } \\
\text { Britain }\end{array}$ & $\begin{array}{l}\text { Community lives together and shares some values and believes; everyone values } \\
\text { it and contributes it. }\end{array}$ \\
\hline 4 & 33 & M & BA & $\begin{array}{l}\text { Madang } \\
\text { Province }\end{array}$ & $\begin{array}{l}\text { Group of people, who are unique, they doing their life in their way, dressing or } \\
\text { so. }\end{array}$ \\
\hline 5 & 26 & M & $8^{\text {th }}$ grade & $\begin{array}{l}\text { Madang } \\
\text { Province }\end{array}$ & $\begin{array}{l}\text { Something like custom or something, which we respect. Ancestors celebrated } \\
\text { this way of life. }\end{array}$ \\
\hline 6 & 25 & M & $10^{\text {th }}$ grade & $\begin{array}{l}\text { Madang } \\
\text { Province }\end{array}$ & $\begin{array}{l}\text { Way of living certain society. From my experience we loose our culture if we } \\
\text { don't teach children to maintain culture. Young generation is forgetting culture, } \\
\text { in the future we loose culture. }\end{array}$ \\
\hline 7 & 27 & M & $10^{\text {th }}$ grade & Chimbu & $\begin{array}{l}\text { Culture is traditional believes, dressing, way of talking, of living, how we use } \\
\text { traditional medicines, liquidizes this knowledge; tapa clothes, got to fight, gar- } \\
\text { dening, stone axe. }\end{array}$ \\
\hline 8 & 23 & M & High school & $\begin{array}{l}\text { Morobe } \\
\text { Province }\end{array}$ & Way of everything we do, from farming to spells. \\
\hline 9 & 27 & M & High school & Sandaun & $\begin{array}{l}\text { Culture is like traditional world of living. We celebrate culture by singsing, grass } \\
\text { skirt, tapa cloth; Our ancestors and parents. How ancestors have been in past. } \\
\text { More like shifting to modern. }\end{array}$ \\
\hline
\end{tabular}

Tab. 2. Definition of culture by respondents.

Currently many Papuans understand that they have to protect the cultural diversity of Papua New Guinea in the wind of change coming from the West. Everyone can diagnose tensions between past and present in this state. The long-term try to balance sociocultural changes and to integrate incompatible world of Papua and West is expressed in The Constitution as corner stone of independence. Preamble of The Constitution of Papua New Guinea among others declares: "We, the people of Papua New Guinea ... pledge ourselves to guard and pass on to those who come after us our noble traditions and the Christian principles that are ours now".

Some of my respondents pointed out that concerning the progressing sociocultural changes that it is very important to protect some elements of traditional way of life. They mentioned key role of young generation and willingness of parents to teach children ancestral customs. It both depends on individual and community decision. Why is actually the tradition preservation so important? In my interviews I asked the question: "Do have traditions their place in the modern world?" A respondent from Morobe province explained this issue by the following words: "we don't have identity of PNG, but identity of different provinces, villages”. Man from Eastern Highlands said that the traditional singsing and dressing is specific for different villages: "If we mix them that is a lost of identity" and added: "Important is sense of identity and not everyday life in the past". Just occasionally Papuans celebrate culture of ancestors (tumbuna taim in tok pisin), especially by the occasion of a child-birth, a marriage, a funeral or feast of the Independence day. Then people organize traditional singsing or big cultural show designed for tourists also. One respondent explained this issue: "We can't go to modern world with traditional dress; we have to move aside and after dress up."

An answer to the question "on place of traditions in the moder world" revealed values and attitudes of my respondents. Some of them pointed out necessity to filter both cultural elements from Western and Papuan traditions. Many of them value current state of Papuan positively, because of present wins in compare with past. That is why people prefer steel to stone and plastic to bamboo. My respondents argued that 


\section{Do have traditions their place in the modern world?}

Good: traditional doing something like singsing. Dressing is significant to villages. Specific people has specific dressing; that is part of identity. If we mix them that is lost identity.

Omit: wantok system, sorcery. Hard to separate religion and sorcery. They don't practice sorcery, they believe in it.

2 Yes, constantly we see not naturally changes. Western ideas are coming and we have to filter them. That's way to maintain the identity of me and my culture. Some of Western ideas are good.

3 We have different life style. Some is good to keep, some to omit. Bad one is sorcery, good one is living in permanent house.

It depends on the size of a community, bigger community better maintains their culture. You identify your area, you can
be proud of it.

Woman respected man. Today is different. They don't know their culture, we have education and we don't have the
knowledge of traditions from parents. That is why the cultures don't have their place in modern world.

\begin{tabular}{|c|c|}
\hline 6 & $\begin{array}{l}\text { In the past boys learnt the traditions in the man's house. Many influences by Western. People value modern culture be- } \\
\text { cause they compare past and modern (bamboo vs plastic). It depends on individuals. }\end{array}$ \\
\hline 7 & $\begin{array}{l}\text { It is important to protect traditional way of life. Because of identity, we don't have identity of PNG, but identity of dif- } \\
\text { ferent provinces, villages. In other countries they use terrorists and pay them for killing people. In PNG we use sorcery. }\end{array}$ \\
\hline 8 & $\begin{array}{l}\text { It is not good to completely omit traditions. This is touristic matrix. We can't go to modern world with traditional dress, } \\
\text { we have to move aside and after dress up. }\end{array}$ \\
\hline $\begin{array}{l}\text { Western way sometimes solves the problems; stopping problem of adultery, lend rights (woman has } 50 \text { per cents). That } \\
\text { means man doesn't have much power, support and benefit of family. Controlling of all rights also solve the problems. }\end{array}$ \\
\hline
\end{tabular}

Tab. 3. Evaluation of traditions by respondents

some traditions are good to omit, some to protect. In other words, traditions are not trash and modern Western world not always brings good things. Papua faces "bad things" coming from West; for example drugs, alcohol, prostitution, robbery, all of them bring destructive effects on local cultures of Papua. Especially, when we combine Papuan and Western way of thinking and problem solving. My respondents evaluated impacts of West on Papua New Guinea, when I asked the following question: "Can you identify five positive and negative impacts of European Civilization on PNG?" My respondents positively evaluated development, technologies, dressing, infrastructure and medical care. The most often they mentioned education as highly positive effect of contact with the Europeans. All of them expect from their children to be educated as the best way to get a good job. On the dark side of the impact is a criminality, drugs, logging, new diseases, pollution and many others (see table 4).

Representatives of governmental and non-governmental organizations, tourists, travelers and anthropologists again and again suggest to the Papuans that their cultures and languages are important and unique. It is then not surprising that you can discuss concept of culture with the natives even in the most remote areas of Papua New Guinea. Inhabitants of this country quickly adapted to this trend. They even founded their trading strategies on their noble traditions. As Linneik pointed out, tradition sells: tourist art, cultural show, t-shirts with Papuan motifs and other types of souvenirs (Linneik 2004). Similarly as others Pacific people Papuans answer to the images of others, which are constructed in the guidebooks and travel books. They create saleable images of the "land that time forgot", and they offer this one to those who arrive to see the „savage Papua“. They have a know-how to sell their cultures. In this respect Silvermann remembered one tourist, who participated in "Cannibal Tours" in famous Sepik area. During the trip he taped a movie and consequently he gave the copy of the film to the villagers as an expression of thanks. Few weeks later he saw that villagers sell the copy of the film as souvenir (Silvermann 2004). 


\begin{tabular}{|c|c|}
\hline \multicolumn{2}{|c|}{ Can you identify five positive and negative impacts of European Civilization on PNG? } \\
\hline Positive impacts & Negative Impacts \\
\hline Education (9) & Sociocultural changes $(7)$ \\
\hline Infrastructure and technologies (7) & Robbery, killings and raping $(7)$ \\
\hline Medical care (6) & Pollution of environment (5) \\
\hline Money (4) & Food processing (3) \\
\hline Permanent buildings (3) & Diseases (2) \\
\hline Clothing (2) & Drugs and alcohol (2) \\
\hline Peace (2) & Laziness (2) \\
\hline Religion (2) & Logging (2) \\
\hline Adopting children by waitman & Money (2) \\
\hline Development & Night clubs (2) \\
\hline Employments & Pornography and prostitution (2) \\
\hline Food & Changing of importance believing \\
\hline Government system & Corruption \\
\hline Intermarriages (other countries) & How ladies dressing \\
\hline Living standard & Inferiority syndrome \\
\hline Personal ways of improving & Lost respect to parents \\
\hline Nature conservation & Lost traditional knowledge \\
\hline \multirow[t]{3}{*}{ Resources } & Lost vernaculars \\
\hline & Traditional marry no more \\
\hline & Western style solving problems \\
\hline
\end{tabular}

Tab. 4 Evaluation of the Western impact on PNG

\section{CONCLUSION}

The visualization through the drawing falls into the category visual anthropology. Unfortunately this one is focused especially on the movie and photography. But drawing represents specific type of narration that is why I think of drawing as important tool for study of the visuality of culture. However, in a current anthropological discourse drawing is rather marginal research tool. It is not possible to mark gathered and interpreted drawings as compact data-set. That is due to circumstances of their origin as I had to answere to the unexpected fieldwork situation. The way of gathering the drawings was not a clear and sophisticated method. During my next stay in the Yawan community (2011) I will focus on study of this local community through this type of visualization. My intention is try to develop a suitable method and build a solid data-set.

Another question of the concept of the culture itself. In post- modern anthropology the concept of culture is under the attack. Postmodern anthropologists argue that culture is an emic category of the West. If we use this concept in the study of others, we are sinners. And the name of the sin is "ethnocentrism". Some anthropologists believe that they may abandon this problematic category, but at this time "culture" is widespread around the word. As pointed out by James Clifford, anthropology is a victim of its own success. Anthropologists exported concept of culture during the $20^{\text {th }}$ century into the world (Clifford 2005). Kuper did clear a diagnosis: "Everyone is into culture now" (Kuper 2000: 2). In this respect culture is very successful "meme" infecting mind whenever it could do. Keesing was right, when he wrote: “Yanomamö culture, 'Japanese culture', 'the evolution of culture', 'nature vs culture': we anthropologist still using that word, and we still think it means something" (Keesing 1974: 73). For anthropologists culture maybe means nothings, but for Papuans it means something: noble traditions and the Christian principles that are ours now. 


\section{LITERATURE}

Barley, N. (1983): The Innocent Anthropologist. London: A Colonnade Book Barley, N. (1988): Not a Hazardous Sports. New York: Henry Holt and Co.

Bláha, J. - Soukup, M. - Balcerová, M. (2011): Mentální mapy obyvatel vesnice Yawan v interdisciplinární perspektivě. Kartografické listy, 19. v tisku.

Bodrogi, T. (1961): Art in Northeast New Guinea. Budapest: Publishing House of the Hungarian Academy of Sciences.

Brown, P. (1979): Highland Peoples of New Guinea. Cambridge: Cambridge University Press.

Carrier, J. (1992): Introduction. In: J. Carrier. (Ed.), History and Tradition in Melanesian Anthropology (s. 1-37). Berkeley: University of California Press.

Clifford, J. (2005): Re-Articulating Anthropology. In: Segal, D., Yanagisako, S. (Eds.), Unwrapping the Sacred Bundle: Reflections on the Disciplining of Anthropology (s. 24-48). Durham: Duke University Press.

Errington, F., Gewertz, D. (1996): The individuation of tradition in a Papua New Guinean modernity. American Anthropologist, 1, 114-26.

Grimshaw, A. (2003): The Ethnographer's Eye. Cambridge: Cambridge University Press.

Groube, L. (1986): Waisted axes of Asia, Melanesia and Australia. In: G. Ward (Ed.), Archaeology at ANZAAS, 1984 (s. 168-177). Canberra: Canberra Archaeological Society.

Haddon, A. C. (Ed.). (1935): Reports of the Cambridge Anthropological Expedition to Torres Straits: General Ethnography. Cambridge: University Press.

Keesing, R.M. (1974): Theories of Culture. Annual Review of Anthropology 3, 73-97.

Kuper, A. (2000): Culture: The Anthropologists' Account. London: Harvard University Press.

Lewis, P. (Ed.). (2009): Ethnologue: Languages of the World. Dallas: SIL International

Linnekin, J. (2004): Tradition Sells: Identity Merchandise in the Pacific Islands. In: V. Lockwood (Ed.), Globalization and Culture Change in the Pacific Islands (s. 324-338). New Jersey: Prentice Hall.

Martlew, M., Connolly, K. (1996): Human Figure Drawings by Schooled and Unschooled Children in Papua New Guinea. Child Development, 6, 2743-2762.

Montgomery, S., Bishop, N. (2006): Quest for the Tree Kangaroo: An Expedition to the Cloud Forest of New Guinea. Boston: Houghton Mifflin Harcourt.

Rappaport, R. (1984): Pigs for the Ancestors. New Haven: Yale University Press.

Silverman, E. (2004): Cannibalizing, Commodifying or Creating Culture? Power and Art in Sepik River Tourism.In: V. Lockwood (Ed.), Globaliza- tion and Culture Change in the Pacific Islands (s. 339-357). New Jersey: Prentice Hall.

Soukup, M. (2009): Základy kulturní antropologie. Praha: AVS.

Soukup, M. (2010): Anthropology in Papua New Guinea: History and Continuities. Anthropologia Integra, 2, 45-54.

Soukup, M. (2011): Vizuální antropologie: vznik, vývoj, milníky. In: Čeněk, D., Porybná T. (Eds.), Vizuální antropologie - kultura žitá a viděná (s. 15-23). Červený Kostelec: Pavel Mervart.

Stuchlík, M. (1964): Etnografie mimoevropských oblastí (vývoj společnosti a kultury) II. Oceánie. Praha: Státní pedagogické nakladatelství.

Wegmann, U. (1990): Yau Anthropology Background Study. S.1.: SIL Papua New Guinea.

Weinberger, E. (2011): Lidé od kamery. In: Čeněk, D., Porybná T. (Eds.), Vizuální antropologie - kultura žitá a viděná (s. 219-251). Červený Kostelec: Pavel Mervart.

Welsch, R. (1998): An American Anthropologist in Melanesia. 2 sv. Honolulu: University of Hawai' i Press.

West, P. (2006): Conservation Is Our Government Now: The Politics of Ecology in Papua New Guinea. Durham and London: Duke University Press.

\section{AUTHOR}

Soukup, Martin (26. 3. 1977, Praha), Czech culturologist and cultural anthropologist. Assistant professor of Department of Cultural Studies (Culturology) at The Faculty of Arts, Charles University in Prague. He also teaches at The Prague College of Psychosocial Studies. He focuses on history, methodology and theory of anthropology, bioculturology and philosophy of man and culture. Soukup is particularly interested in the cultural area of Melanesia. In 2009 he undertook anthropological pre-research in Papua New Guinea in three local communities - Wannang (Madang Province), Kegeslugel (Chimbu Province) and Yawan (Morobe Province). In 2011 he came back to Yawan. Besides number of papers and article, he is also the author of the textbook Essentials of Cultural Anthropology (2009, in Czech). This book was awarded by Charles University as excellent monograph. He published monographs Bioculturology: Evolution and Culture (2010, in Czech) and Culture: Bioculturological perspective (2011, in Czech).

Contact: PhDr. Martin Soukup, Ph.D. The Department of Cultural Studies (Culturology), Faculty of Arts, Charles University in Prague, Celetná 20, 11000 Prague 1, e-mail: martin.soukup@ff.cuni.cz. 
